\title{
Making sense: Experiential engagements with ethnographic photographs
}

Christine Horn*

\section{Abstract}

This article examines the role of embodied and performative knowledge in the museum environment, with a particular focus on ethnographic photographs. The study is based on the return of several hundred ethnographic photographs from the Sarawak Museum to Indigenous communities in rural Malaysia, where they had been taken by museum photographers from the early 1950 s onwards. Aside from the oral narratives that emerged during the discussions and interviews, contextual knowledge was provided in embodied form. The return of the photographs to people in the source communities prompted the re-enactment of activities, retelling of stories and production of cultural heritage to which the photographs referred. Such embodied knowledge, defined as knowledge preserved through performance and embodied activities, relates to the multi-vocal narratives about objects that museums are increasingly trying to include in their exhibitions. In this article I argue for a greater and more experimental use of sensory means to convey information about artifacts to museum audiences.

Keywords: Ethnographic photographs, Photography, Embodied knowledge, museum archives, Sarawak, Southeast Asia

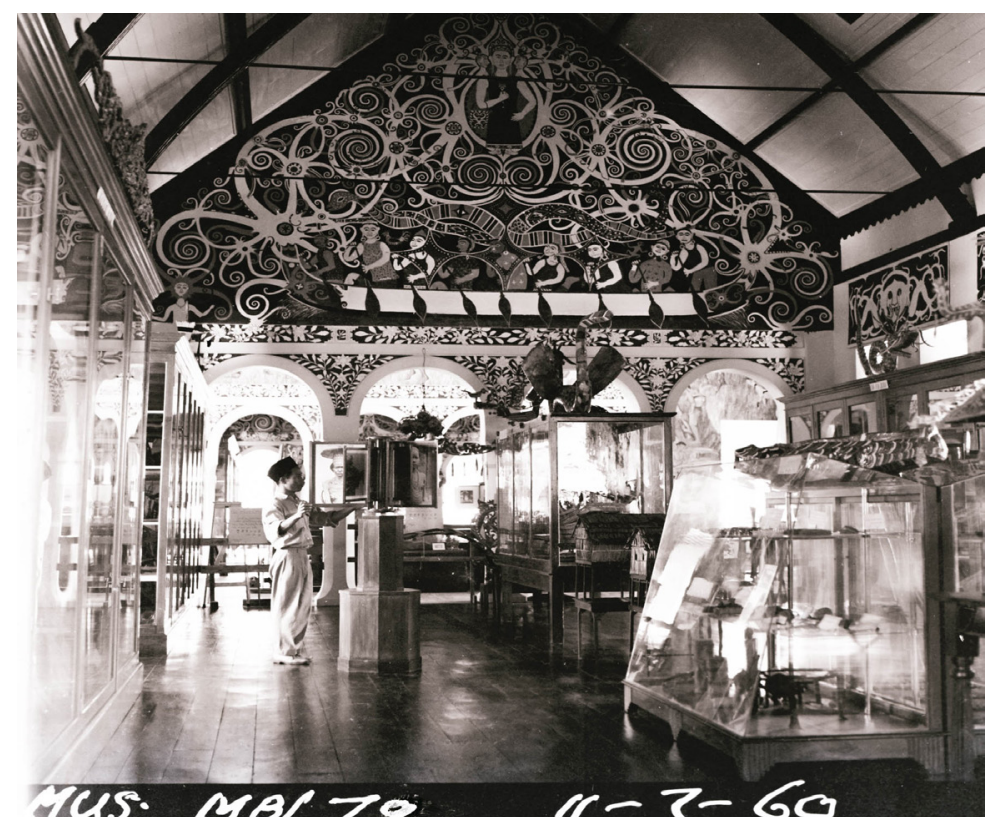

Figure 1. Man looking at photographs in the ethnographic section of the Sarawak Museum, 1960 


\section{Introduction}

The photograph above was taken at the Sarawak Museum in Malaysia in 1960 and shows the interior of an ethnographic exhibition (see figure 1). A man wearing a Malay songkok, a black conical felt hat, is standing in front of a rotating stand with framed photographs. He is looking at a photograph of a woman wearing a wide-brimmed hat.

The photograph illustrates the way that objects at museum exhibitions were often placed within reach of audiences and yet beyond it, since visitors were not allowed to handle them. In this the Sarawak Museum policies regulating audience behaviour resembled those of most other museums at the time. In general, museum visitors were expected to keep their hands off while gazing at the objects on display without engaging in sensory exploration of the object. The use of photography for establishing explanatory narratives and as a background to descriptive texts ties in with the preference for visual engagement, as figure 1 suggests. At the Sarawak Museum, staff used photographs from its vast archives such as this one to provide context for the objects and support the narratives provided alongside the objects. Another photograph, a close up of a glass case at the Sarawak Museum in 1966, shows how photographs were used by museum workers to accompany objects and illustrate their usage or manufacture (see figure 2).

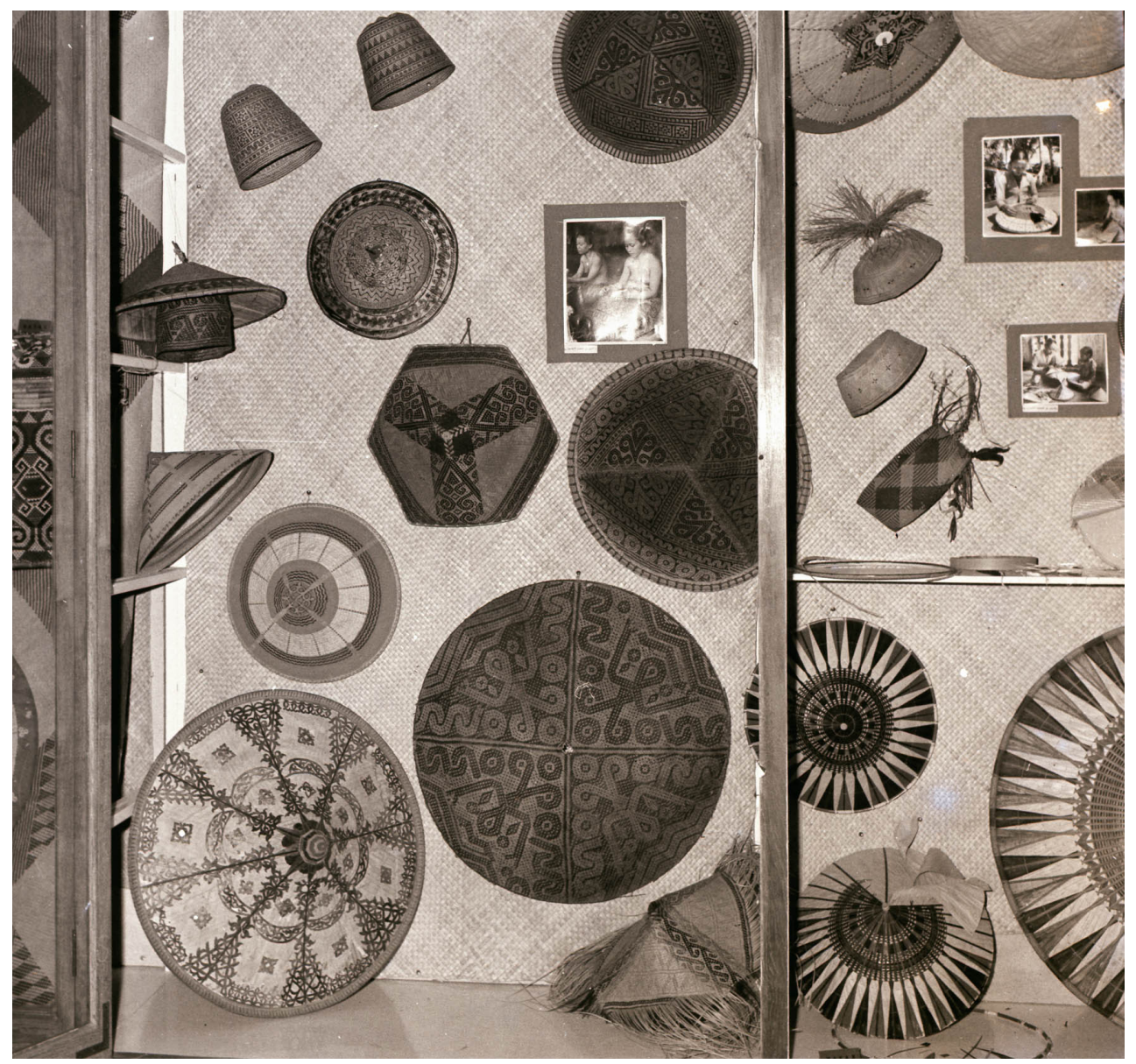

Figure 2. Content of a glass case at the ethnographic section of the Sarawak Museum, 1966 
Figure 2 shows an open glass case filled with numerous kinds of local hats, wide and highly ornamented sun-hats as well as decorative rattan headdresses. Photographic prints are mounted in between, showing women making the hats. Figure 2 illustrates how photographs were commonly used 'to authenticate other classes of objects' (Edwards and Mead, 2013: 21) and to provide historical context in a museum environment and to reinforce the narratives prepared by museum workers.

In this article, I will argue that photographs can be used to engage in more reciprocal methods of generating knowledge about museum collections which include not only written and oral narratives but also experiential and embodied knowledge. This is because photographs prompt the re-enactment of activities, re-telling of stories and production of artifacts that are part of the cultural heritage of a community. Museum objects, including photographs, can serve as reminders of activities and practices that, for whatever reason, have ceased to be part of the cultural repertoire. They can prompt people to revive and even re-appropriate such practices, which rely on embodied and experiential knowledge for their continued existence, as part of their cultural traditions.

Embodied knowledge is here defined as knowledge that is preserved through performance and embodied activities, in opposition to knowledge transmitted via texts or oral history. In the words of Standal and Moe, "embodied learning is tied to a form of knowledge that primarily expresses itself in acts' (Standal and Moe, 2011:261), which suggests that embodied knowledge is performative and experiential, as people enact, rehearse, and imitate activities. This relates to Bourdieu's argument about embodied kinds of cultural capital (Bourdieu, 1986), although this argument is not central to this article. This kind of knowledge is 'embodied, performed, and narrated, experiential rather than symbolic, and resonant with ontological traditions practiced by non-Western local, rural, and indigenous peoples' (Srinivasan, 2012: 3).

I draw from a growing body of work from that substantiates the wider relevance of embodied and sensory knowledge for the museum field (Howes, 1990, Classen and Howes, 1996, Classen and Howes, 2006, Hubard, 2007, Isaac, 2011, Wood and Latham, 2011, Howes, 2012, Dudley, 2013, Howes and Classen, 2013, Classen, 2014, Clintberg, 2014, Howes, 2014a, Levent and Pascual-Leone, 2014, Pallasmaa, 2014, Johnson, 2015).

As instances of embodied knowledge I discuss activities that came about as a response to people's engagement with museum photographs during my work in Sarawak's rural north (see map 1). The photographs I circulated in the communities here showed traditional artifacts, practices and environments which I used to engage people in a discussion about their content. In response, the photographs were not only discussed but performed. Many of the photographs prompted the enactment of embodied knowledge, for instance those showing traditional basketry, food processing and practices such as cast-net fishing, among others. In this article I will review some of these activities and the way they relate to the role of photographs in a museum context, and how they tie in with recent work on the senses at the museum.

For my research I used data collected during four years of work with the Sarawak Museum archive in Kuching, Malaysia. The Sarawak Museum archive contains thousands of photographs from various Indigenous communities in the region, most of which were taken from 1950 onwards. Using observations and interviews made during this research, I argue that photographs provide links to embodied knowledge that may contribute to the multi-vocal narratives contemporary museums are increasingly trying to integrate into their exhibitions (Phillips, 2003, Marstine, 2008). Greater efforts to work with subject and source communities of ethnographic photographs can provide curators and museum workers with new insights into the embodied practices that relate to their collections. A combination of textual, oral and embodied knowledge can provide a layered and multi-vocal interpretation of artifacts. In addition, I suggest that embodied knowledge can contribute to existing strategies of engaging visitors at museum exhibitions.

\section{Photography and ethnography}

Ethnographers discovered the potential uses of photographic documentation for their work as early as the 1830s (Pinney, 2011). For anthropologists, the technology enabled what were perceived as direct, detailed and unchanging documents suitable to validate scientific 
observations (Hartmann etal 1998; Grimshaw 2008). However, early ethnographic photographers were restricted by cumbersome machinery. Cameras were large and unwieldy and photographic plates required the subjects to remain motionless during long exposure times and did not permit photographs under low light conditions. Thus many early ethnographic photographs were either taken in studio settings or had to be meticulously staged (Appadurai 1997).

With increasingly portable technologies, anthropologists and ethnographers started to use photography in the field. An early practitioner was Charles Hose, who worked in in Sarawak as a government servant. Hose maintained personal and professional relationships with the communities who were the subject of his ethnographic studies, which permitted him to add detailed information about the people in his photographs (Hose, 1894, Hose, 1900, Hose and McDougall, 1901). Once published, his ethnographic descriptions shaped public understanding of Sarawak's Indigenous groups for a century.

Indigenous people in Sarawak were aware of the impact of such representations. In Borneo, one early photographer noted: 'On some occasions I heard old men explain that they would not want to be photographed, because their pictures might be later put in a book and seen by everybody' (Nieuwenhuis, 1904). Indeed, concern over the descriptions and narratives surrounding photographs is at the centre of criticism of colonial-era ethnographic photographs. Photographers frequently failed to engage with the individual identities of the people in photographs, reducing them to types instead (Appadurai, 1997, Poignant, 2004, Bradley et al., 2013, Maxwell, 2013). Photographs accompanied and seemed to illustrate ethnographic descriptions and narratives about people who were unable to represent themselves (Smith, 1999). Because of this seeming inequity inherent in ethnographic photographs, ethnographic collections and their creators have come under critical scrutiny in the past decades (Dibley, 2005, Maxwell, 2013, Binter, 2014, Modest, 2014).

\section{Visual repatriation and return}

One increasingly common way of investigating ethnographic photographs and their contemporary significance is for researchers to take collections back to the communities where they were taken and encourage people to discuss their views and opinions (Bell, 2003, Curtis, 2006, Smith, 2008, Geismar, 2009, Peers and Brown, 2009a, Isaac, 2011, Dobbin, 2013). These engagements can lead to insights into how communities experienced the role of photographic subject (Bradley et al., 2013) as well as the effects of colonialism and its aftermath (Simpson, $2009 b)$. Such projects can also engage with narratives about the history, culture and traditions of the communities from the point of view of those who practice them, or used to practice them (Lydon, 2010). Photographs can be useful for Indigenous communities who are able to re-interpret ethnographic photographs according to the narratives and culturally- and communally-derived knowledge of the community. Tsinnahjinnie's term for this is 'photographic sovereignty' (Tsinhnahjinnie 2003: 42).

The practice of returning photographs to source communities has received growing academic attention as communities are increasingly requesting the repatriation of museum objects, in particular those deemed of spiritual value, such as sacred objects or human remains (Simpson, 2009b, Simpson, 2009a, Christen, 2011, Pickering, 2015). While the ownership of objects is usually transferred to the communities upon repatriation, photographs may be returned in the form of printed or digital copies while the ownership and all the rights this entails remains with the institution. Because of this, such research is now more commonly referred to as 'return' instead of 'repatriation' (Lydon, 2010).

In many ways, the potential for distribution offered by digital archives has complicated the issue of photographic return. Museums can make their archives accessible globally online and, in theory, users from source communities could provide feedback and input (Smith, 2008). On the other hand, copyright issues and concerns about the appropriation of Indigenous cultural heritage have limited this kind of usage (Janke and lacovino, 2012).

\section{Photographs, museums and the senses}

Photographs fit neatly into what has been called the 'visualist' model of Western society (Classen, 1997). The term refers to the dominance of the visual sense over other senses, a 
social model of the senses that manifested itself in the field of anthropological research in the nineteenth century (Howes, 2003). In this context, photography presented a suitable mechanism for scientific and academic documentation (Pinney, 2011). An increasing focus on empirical evidence in the scientific disciplines more generally, and researchers' growing emphasis on underscoring their arguments and hypotheses through scientific observation, contributed to this development (Classen, 1997, Classen and Howes, 2006). As Pels has put it, 'Observation... reflects centuries of so-called visualist bias in the culture of Western science, to which the role of other sensory registers in producing knowledge was subordinated' (Pels, 1997). The visual sense came to be seen as related to the mind, while the other senses were seen as more closely associated with the body, and therefore were thought of as less advanced (Classen and Howes, 2006). This preoccupation with the visual over other senses has also been called 'ocularcentrism' (Edwards, 2006, Geisbusch, 2012).

The 'primacy of the visual' (Edwards, 2006: 28) manifested itself at museums, even though historians of the institution argue that this has not always been the case (Geisbusch, 2012, Classen, 2014, Howes, 2014b). Weighing objects in one's hands, rubbing and smelling them was in fact considered an essential part of the experience once (Howes and Classen, 2013). In spite of this history of sensory exploration of objects at museums, '[t]he use of the non-visual senses came to be seen as coarse, uncivilised, and even as potentially damaging to the exhibits' (Howes, 2014b), and as a result of this, objects were locked away in glass cases. In Sarawak just like in most countries around the world, 'the sense of vision ... dominated museum and exhibition designs throughout the era of modernity' (Pallasmaa, 2014: 239).

\section{The corporeal turn}

Much has changed in museum theory in the last decades. A growing number of writers point out that all the senses play an important role for museum audiences and the acquisition of knowledge at museums, whether or not this engagement is made explicit (Classen and Howes, 2006, Dudley, 2013, Pallasmaa, 2014, Pye, 2016). Following the 'corporeal turn' in the early 1990s, writers increasingly argue for a greater focus on the senses in sociology and anthropology (Classen, 1997, Classen and Howes, 1996, 2006, Clintberg 2014, Howes, 2012, Losche, 2006, Stoller, 1989, Sutton, 2006; Wood and Latham, 2011). Museum scholars have become more attentive to the role of sensory knowledge in what Howes has called 'the sensorial revolution of the past decade or so' (Howes, 2012: 450-451). Compilations such as Museum Materialities (Dudley, 2013), The Multisensory Museum (Levent and Pascual-Leone, 2014) or The Power of Touch (Pye, 2016) are continuing to cast light on how senses can be integrated in museum work. Among museum workers the idea is taking hold that sensory engagement with objects can contribute to audience engagement because 'artifacts body forth specific 'ways of sensing' and they must be approached through the senses, rather than as 'texts' to be read or mere visual 'signs' to be decoded' (Classen and Howes, 2006: 200).

Similarly, writers in the field of photographic theory started to question a purely visual approach to photographic analysis, suggesting that previous 'visualist' interpretations of the photographic medium needed to be revised (Edwards, 2002, Edwards and Hart, 2004, Edwards, 2012). As a result of this theoretical shift, the 'thingness' of photographs (Breitbach, 2011) has increasingly emerged as a subject of academic investigation.

This article focuses on ways of thinking about the relationship between photographs and objects, and between photographs and embodied and sensory experience. In other words, it centres around museum photographs and their relationship to knowledge that is inherent in the things people do and feel. My work ties in with developments in the museum field in the last three decades, as some museums started to integrate multi-sensory experiences into exhibitions, while others employed multimedia installations to engage with audiences (Candlin, 2004, Wood and Latham, 2011, Binter, 2014, Clintberg, 2014, Gadoua, 2014). Methods have included audio guides, interactive displays, guided tours and even extend to more subtle methods like the employment of scents and smells within exhibitions (Howes and Classen, 2013). Children's museums, teaching collections, as well as some science and technology museums, also include interaction and experimentation with objects as well as sensory engagement (Wood and Latham, 2011). 


\section{Photographs in museum exhibitions}

Within the context of a museum exhibition, photographs may not generally be seen as sensory objects since they do not appear dependent on sounds or smells, or offer much by way of materiality. They can nevertheless facilitate embodied experiences. Looking at a photograph together with other people, viewers may discuss the content on display, exchange views, argue about details, recall relevant memories and perform oral narratives (Edwards and Hart, 2004, Geismar, 2009). Viewers may also be prompted to imitate the activities they see in the photographs, as I will discuss below. People's active, embodied engagement with the photographs expressed itself in various ways, from very simple repetition of the poses and stances of the people in the photos to more complex engagements that involved planning and preparation, such as musical performances. Sometimes it seemed almost impossible for viewers not to imitate the people in the photographs. During an exhibition of the photographs in Kuching, Sarawak's capital, many visitors could not resist posing in the same ways as two girls in one of the large framed prints (see figure 3 and 4 ). This is one of the ways in which photographs are 'performed,' as Edwards has put it, as '... photographs operate not only simply as visual history but are performed... as a form of oral history, linked to sound, gesture and thus to the relationships in which and through which these practices are embedded' (Edwards, 2006: 28).

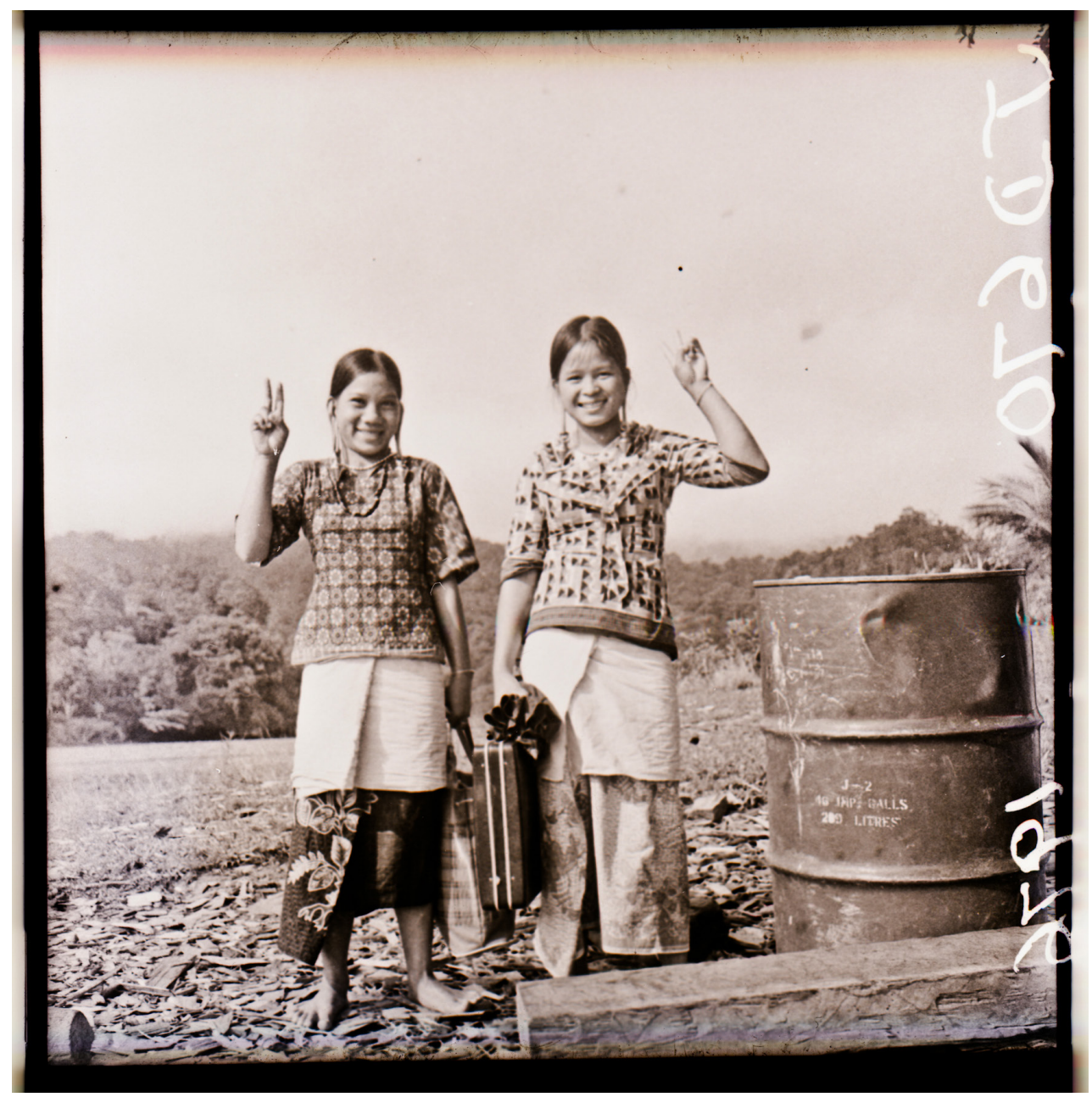

Figure 3. Laong Jalong and Laie Tanyit from Long Makabar 


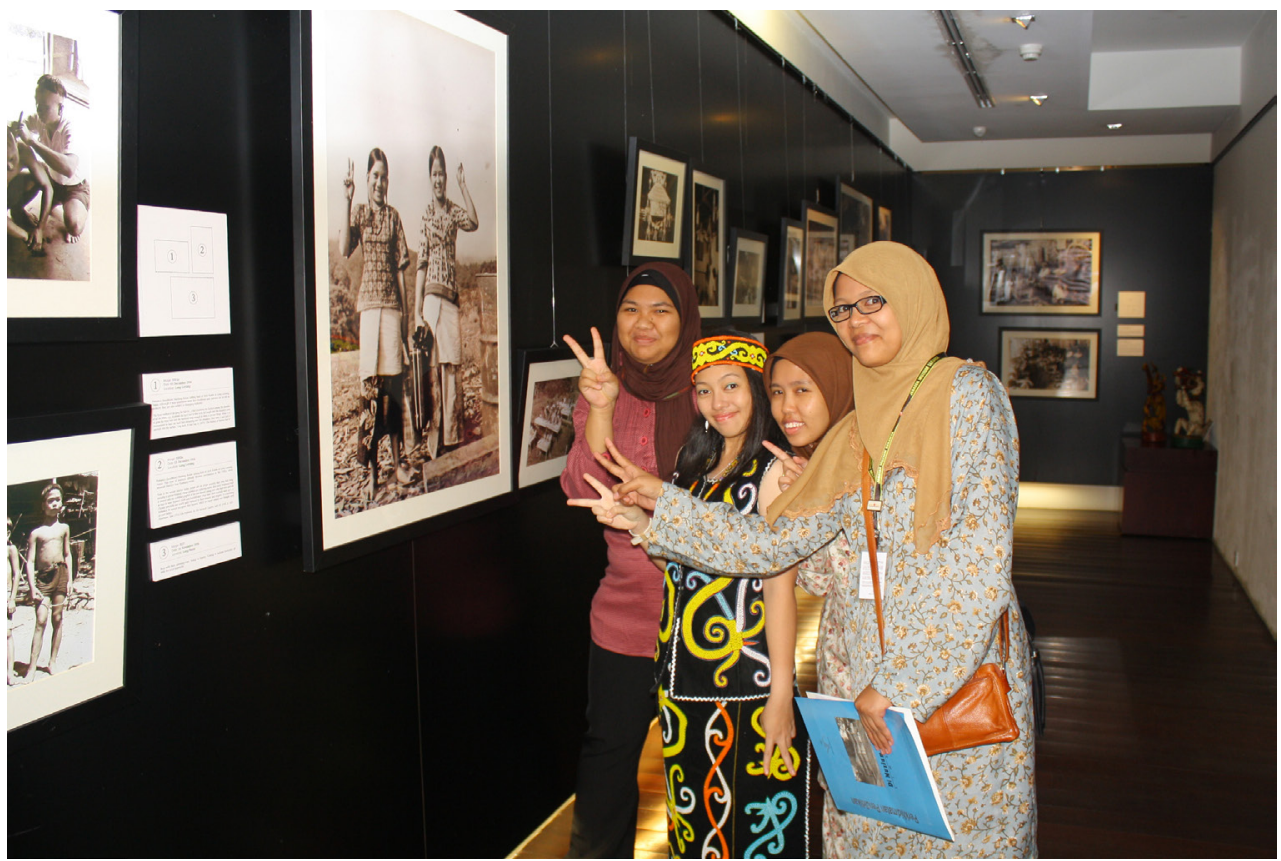

Figure 4. Visitors in the exhibition in Kuching, April 2014

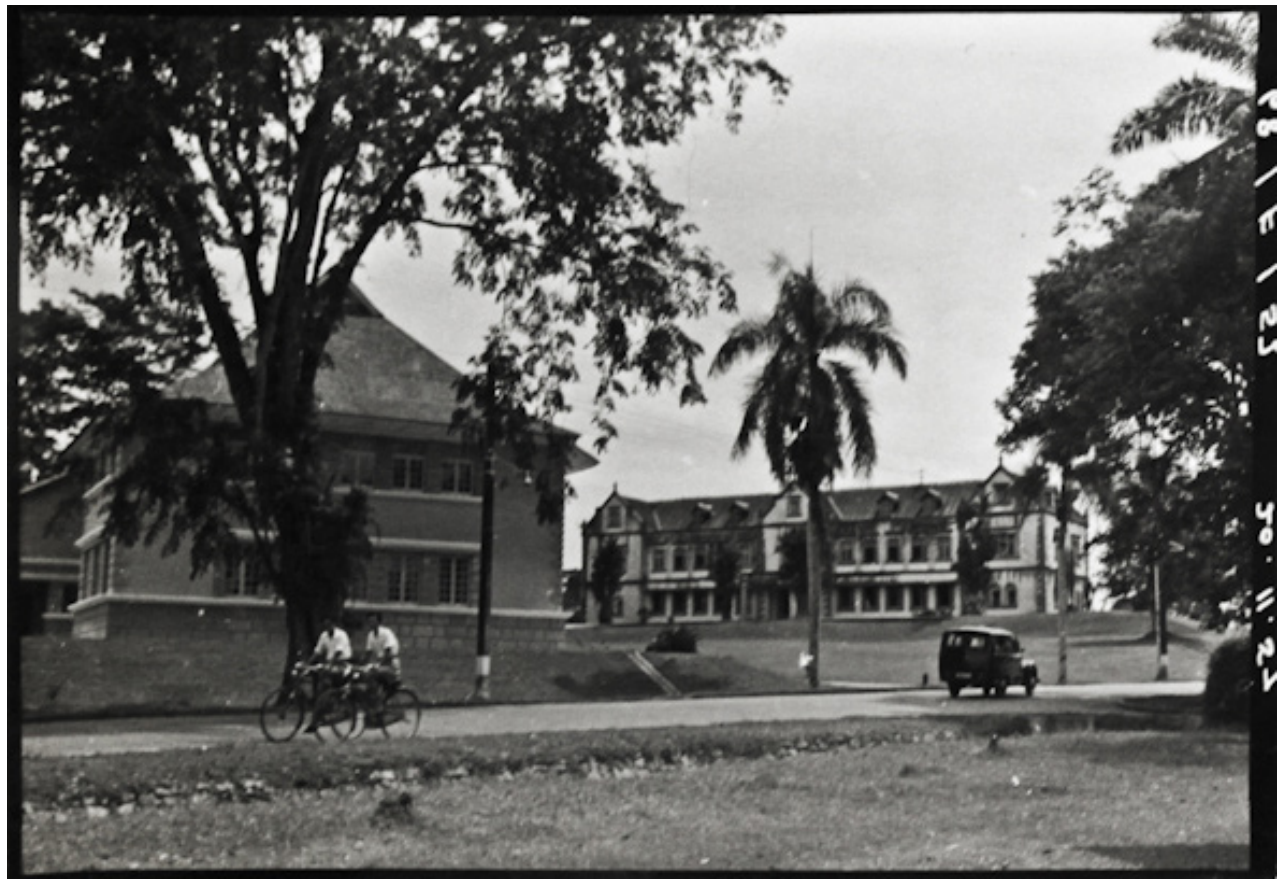

Figure 5. The Sarawak Museum in 1957 
These activities suggest that photographs relate to a wide array of embodied knowledge through which their content is reconstituted. Since they enable these different ways of expressing and transferring knowledge, photographs have the potential to become a tool for museums to link a visual experience to more experiential and sensory ways of relating to museum artifacts. Photographs may also enable creative activities that enhance the understanding of objects, their usage and social roles.

\section{The Sarawak Museum archive}

The photographs discussed in this article belong to the collection of the Sarawak Museum in Kuching, one of two Malaysian states on the island of Borneo (see map 1). They were taken in remote rural communities in the north of Sarawak between 1946 until 1963, the period during which Sarawak was governed as a British colony. Tom Harrisson, the curator of the Sarawak Museum during that period, had initiated the collection and was its first contributor, before a designated photographer became part of the Sarawak Museum staff (Horn, 2013). In 1963 Sarawak was granted independence and shortly afterwards the state joined the Federation of Malaysia. Harrisson left the museum in 1966 but the archive continued to grow as more and more photographs were added under subsequent curators.

The photographers at the museum contributed to exhibitions and showcases and were also attached to staff during research or conservation work. The museum photographer was in charge of taking, archiving and reproducing photographs from the archive, and liaised with researchers who request access. Photography was also used to document the work of Indigenous artists would at times be invited to work at the museum. Above all, however, the photographs were used for museum exhibitions and to illustrate academic articles, books and other publications. All these activities led to the museum archive becoming a vast and diverse collection housed at the Sarawak Museum premises in Kuching.

\section{Methods}

For the research that informs this article I chose a selection of photographs from Baram River and the Tinjar, one of its main tributaries, in the north of the state (see map 1 and map 2). The region is home to numerous minority ethnic groups that are collectively referred to as 'Orang Ulu', which means 'people from upriver' in Malay. The Sarawak Museum photographs were taken in villages and longhouses mostly inhabited by ethnic Kenyah, a group which is subdivided into various subgroups, such as the Sebup, Lepo' Tau and others. Each of these groups has its own cultural traditions and dialects. Many Kenyah are subsistence agriculturalists, although people also grow cash crops. In the past decades, many have found work in the cities and towns near the coast.

The photographs from the Sarawak Museum consisted of medium-format black and white photographs. The research involved some months of archival work during which a section of the archive was indexed and digitized. Then, prints of these photographs were returned to the source communities in some of the rural communities in the interior of the state during several visits between 2010 and 2013. Once the location of a set of photographs had been determined, the photographs were circulated among members of the community. Participants were encouraged to discuss the photographs and talk about their memories and associations during interviews held with individuals. The material was also explored in group discussions that were open to everyone. In all, the project comprised 1500 photographs and visits to 15 communities (see map 2). Many of the photographs included in this project had not been published or exhibited and when they were circulated among the people in rural communities most of the participants had never seen the photographs before. Many had not known the collection existed, and were fascinated to see photographs of their own community fifty years ago. This research resulted in two public exhibitions of the photographs and the photographs along with the community responses were also sold as a book at the Sarawak Museum book shop, mainly to enable people from the communities to own a copy of the collection (Horn, 2012). 
Photographs and cultural heritage, and the role of sensory experience

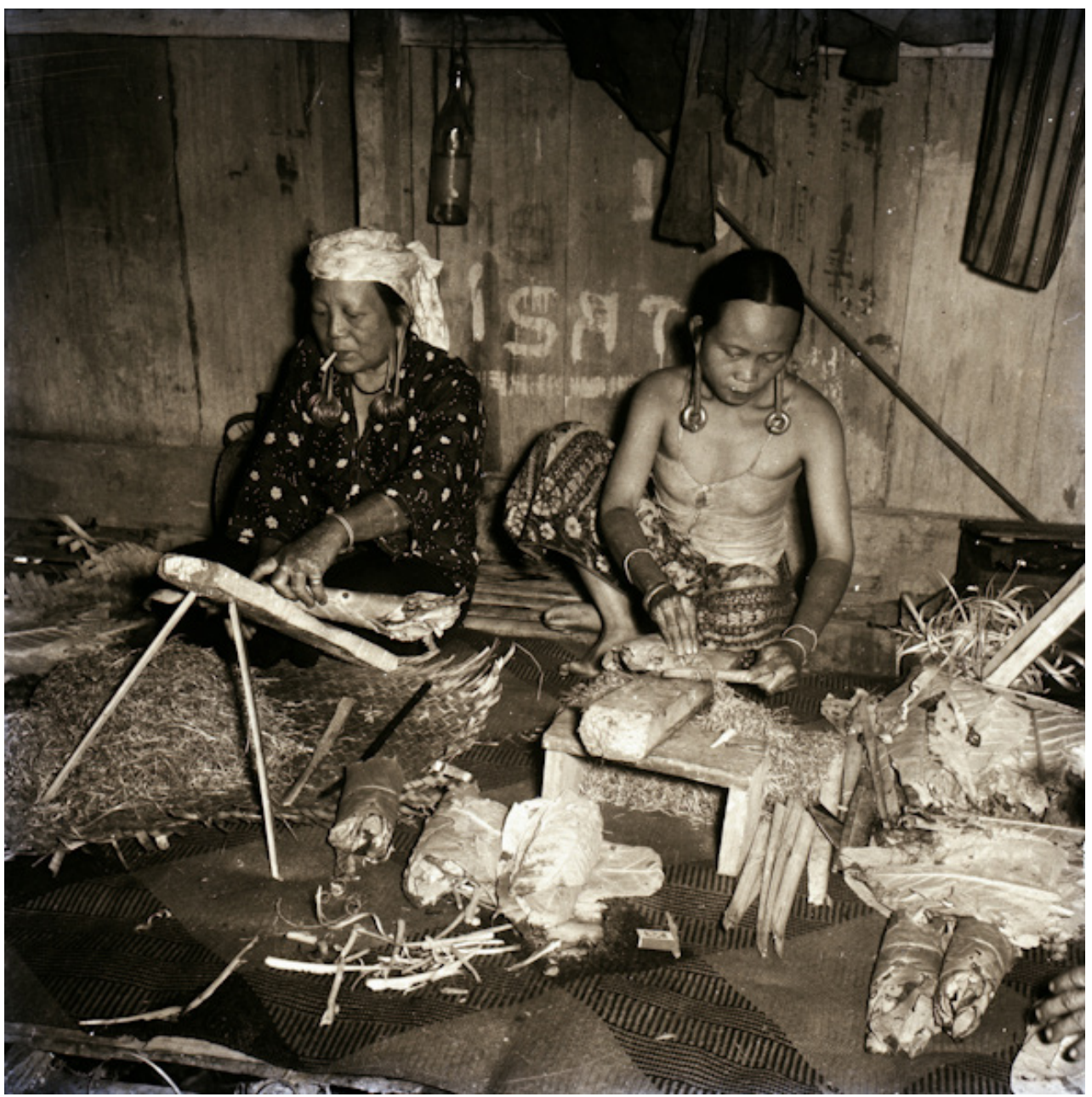

Figure 6. Sekua and Laeng Teging cutting tobacco, 1956

Photographs are often described as 'polysemous' (Ball and Smith, 2012) because they contain many layers of meaning. The diverging narratives that emerged during this research bear this out. People expressed different memories, connotations and ideas about what they saw in the photographs. A single photograph could lead to narratives about various cultural practices. Based on these different stories participants also demonstrated the content of the photographs in various different ways, which included embodied experiences. For instance, one photograph that was included in this research showed two women, Sekua and Laeng Teging, cutting their home-grown tobacco on the longhouse veranda in Long Jegan (see figure 6, see also map 2). The photographs show Laeng with a cigarette on her lips, cutting a wad of leaves into thin strips on a wooden board.

In the Baram region many people still plant, process and smoke their own tobacco, and use dried young banana leaves for cigarette paper. During my fieldwork in Long Loyang and Long Sobeng, several people were processing their own fresh tobacco leaves in the same way. Participants pointed this out to me whenever they spotted the kinds of activities that they had 
seen in the photographs earlier. During my visit Lungah Ganang from Long Sobeng showed me where her neighbour was in the process of preparing the young banana leaves for drying in front of the longhouse, so that I could see how they naturally curled up when they were dry. She also offered me one of her cigarettes to try.

The embodied experiences which emerged as a reaction from participants during my research with the Sarawak Museum photographs seemed at first coincidental. During the course of the research, however, it became evident that instances where scenes from the photographs were demonstrated, imitated or pointed out to by participants enabled me to learn more about the content of the photographs. This information became available in the form of taste, sound and movement rather than in the shape of abstract information delivered via oral narratives. These experiences were as multi-layered as other kinds of knowledge, narratives and memories the photographs prompted, and covered many aspects of local tangible and intangible heritage. The following is another example of such an occasion.

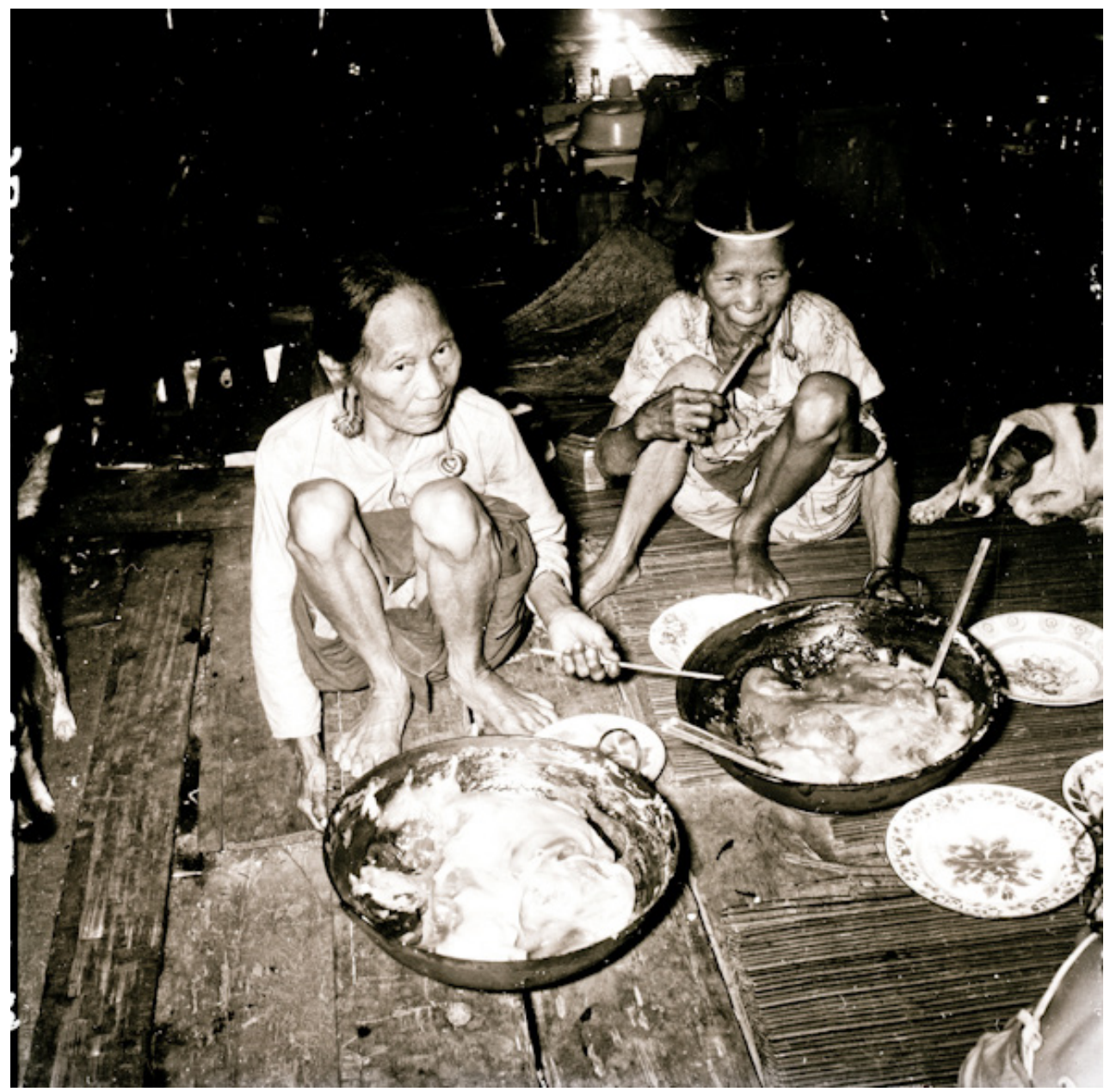

Figure 7. Two women eating na'o in Long Buroi, 1956

Many among the photographs from the Sarawak Museum featured local agriculture, food production and preparation. For instance, the photograph above shows two elderly women eating a dish called na'o. The two are shown seated in front of two large woks filled with dough. In the photograph several plates are placed around the woks, and a dog looks on from the 
side (see figure 7). Na'o, the dish seen in the photograph, is made from tapioca, a starchy root that became a staple in times of rice shortage. Today people mostly buy tapioca flour from a village shop if they want to cook na'o instead of producing it themselves.

During an afternoon of discussions in the course of my research several people from Long Loyang explained the how tapioca was processed, and the different meals that were made from it. Later on the same day a group of four came back with a bag of tapioca flour and the utensils needed to cook and eat na'o, a large wok and a wooden implement that looked like a pair of chopsticks fused at one end. One of the four, a woman called Kapit, went on to demonstrate how the dish is prepared. She poured the flour into boiling water while stirring the mixture as it turned from a transparent liquid into a white glutinous dough. When the meal had been prepared, Kapit showed me how to scoop up a bite-sized amount with the wooden implement made specifically for na'o, and we all tried the dish. The substance has a particular glutinous texture and an indistinct flavour, and is therefore usually eaten with other more flavoursome dishes or salty soup.

In the example described above, the activity of preparing and eating na'o at Long Loyang provided the embodied knowledge about cultural heritage, for instance the process of preparation, the flavour of the dish and the usage of the implements with which the na'o was eaten. These activities linked the photograph to experiential knowledge and material culture. Otherwise put, 'the fusion and performative interaction of image and materiality [provided] sensory and embodied access to photographs' (Edwards, 2006: 27). Description, performance and sensory experience together gave meaning to the photograph. These above mentioned embodied and sensory engagements presented an additional layer of information which was inherent in the photographs which exceeded the kind of information that was transmitted via participant's oral narratives. The meaning of the photograph emerged through creative, interactive and embodied activities.

\title{
Photographs and the conservation of intangible cultural heritage
}

The performances I have described so far in this article tie in with the idea that knowledge is generated and communicated through practice. In Christie's words,

\begin{abstract}
Aboriginal knowledge, like all other knowledge, comes out of the routine practices of everyday life and makes those practices possible. Sometimes particular representations of knowledge become codified in particular ways, as in art and painting -and in databases, university textbooks, and research papers-but normally, knowledge is embedded in the ways people live out their daily lives. It is performative. It should be understood more as something that you do than as something that you have (Christie, 2008: 273).
\end{abstract}

According to this definition, experiential knowledge relies on practice for its continued existence. The encoding of such knowledge through texts or photographs or both can only partially preserve it. This became clear during my research, where embodied practices emerged as a consistent response to the photographs throughout the project. On many occasions, participants organised particular practices they saw in the photographs during an interview or in a group discussion. In other instances, participants demonstrated the practices their friends and neighbours were engaged in, which resembled those in the photographs. For instance, the photographs from the museum showed people working on baskets, making boats or musical instruments. Where these activities were still practiced in the communities, participants consistently pointed them out. In some instances, the kinds of practices shown in the photographs had become rare, and yet some of the participants endeavoured to re-invigorate the practice in order to demonstrate it after they had seen them in photographs. Some of these demonstrations included complex preparations, for instance where dancers, musicians, costumes and props had to be organised, such as the performance described below.

During a visit to Long Nuwah in 2013, one participant named Jenun Batok was particularly interested in one photograph of a woman singing a traditional Kenyah song to welcome visitors. Jenun explained this tradition while looking at the photographs. According to her, the singer praises visitors and host, drawing from her own experience and according to her skills and 


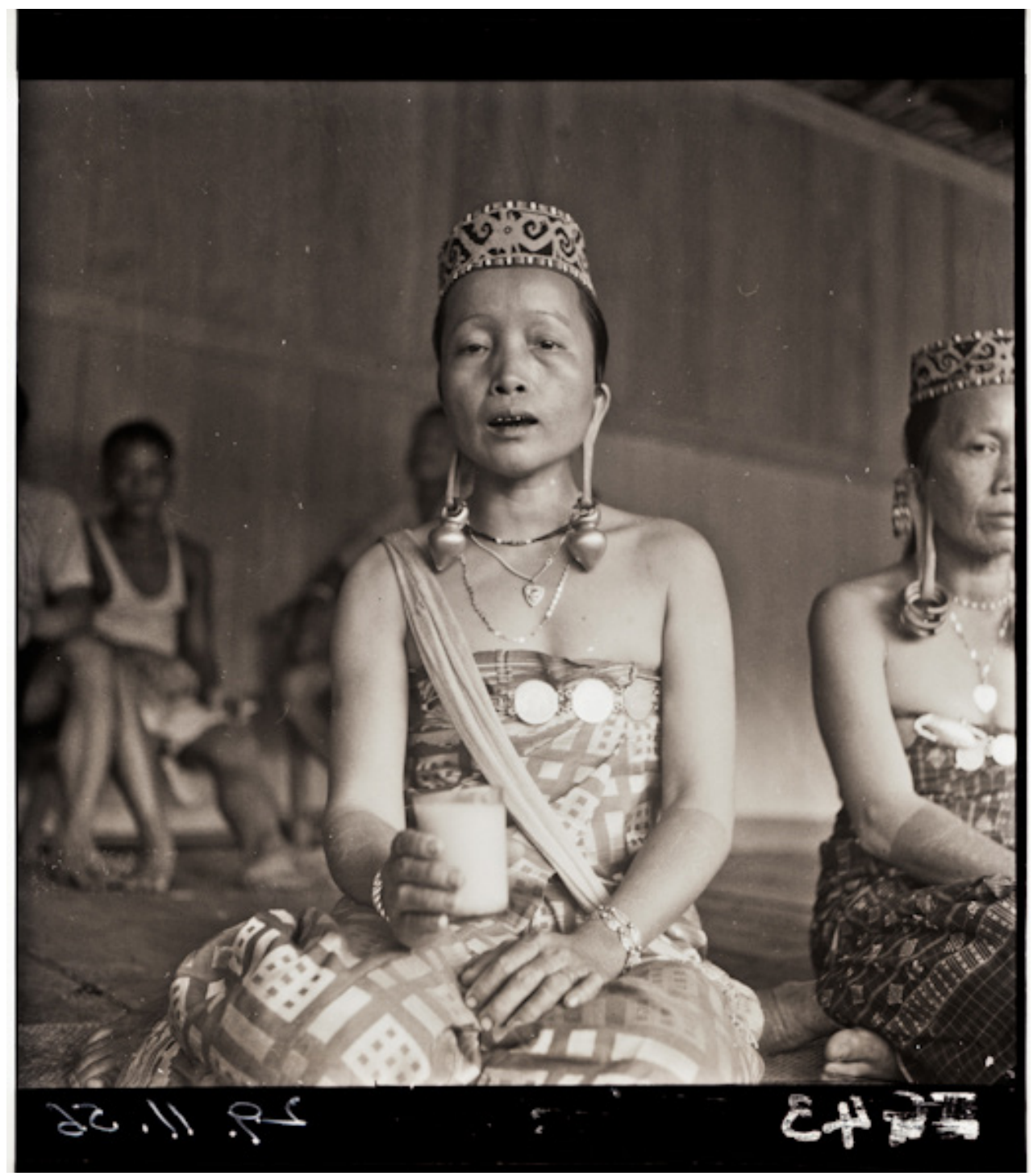

Figure 8. Lalang Saging singing a traditional Kenyah song to visitors, 1956

talent. The lyrics and the melody follow a complex traditional pattern. At the end of the song the visitor is offered a glass of home-made rice wine. The photograph above shows Lalang Saging performing one of these songs in Long Atun (see figure 8).

Following her encounter with the photographs, Jenun re-enacted this tradition together with her husband and several neighbours. In the evening people from the longhouse gathered on the communal veranda. Then, Jenun started to sing in the local Kenyah dialect. 'You have come from very far to visit Long Nuwah', her lyrics went. 'We are happy that you have been able to come to come. Maybe one day, if you invite me, I might also visit you at your home.' At the end of the song she poured a glass of her rice wine, and we drank. 


\section{Photographs and performance as intercultural practice}

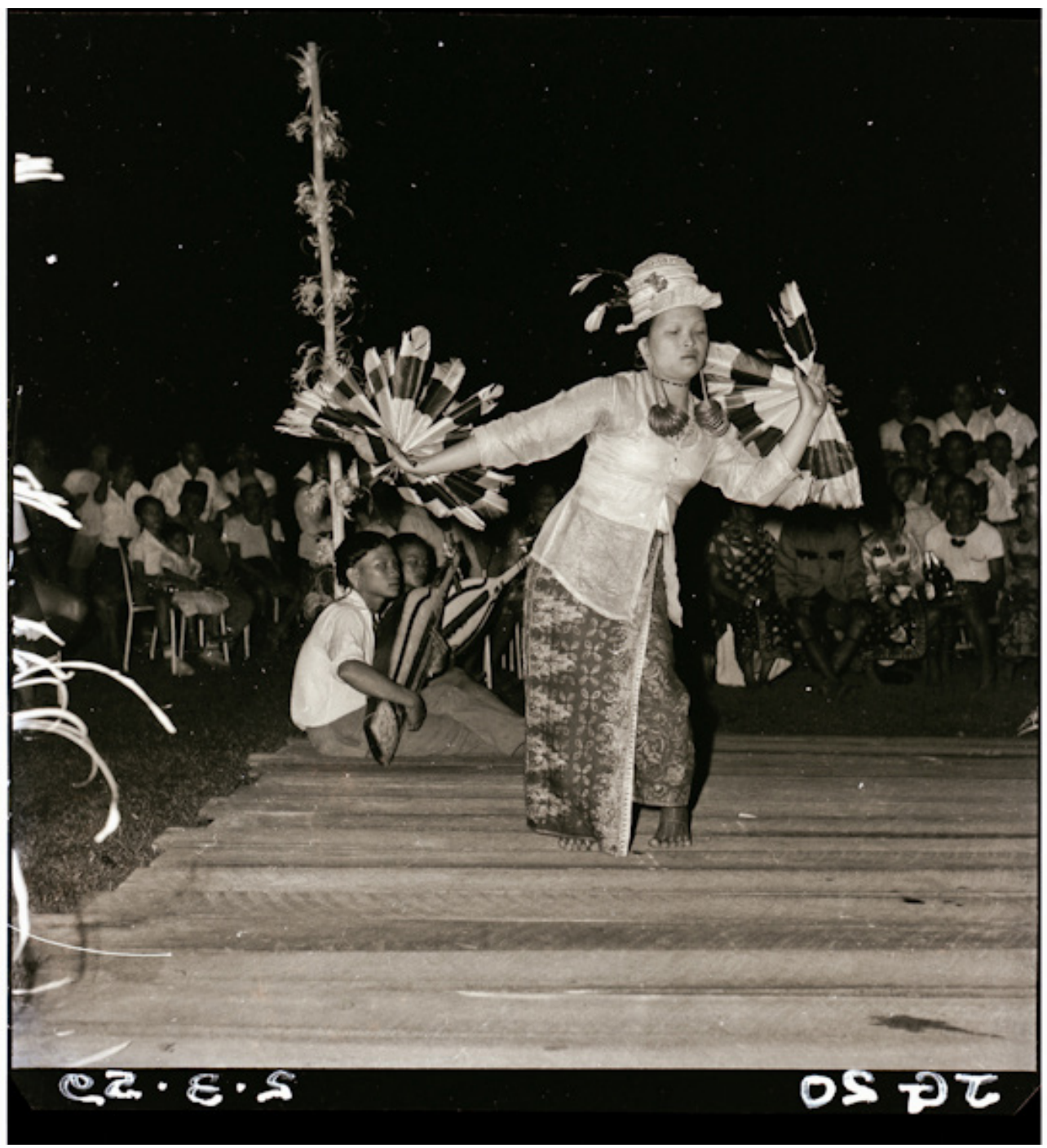

Figure 9. Woman dancing at the Baram regatta, 1959

Sarawak's Indigenous tangible and intangible heritage includes local dances, musical styles and instruments, ornaments, clothes and costumes, among other elements. Many of these were in some way represented in the photographs from the Sarawak Museum archive. A popular dance among women was called the hornbill dance, and there were many photographs in which this particular dance was shown.

The Sarawak Museum collection contains many photographs taken during dance performances, showing the costumes, the rotan headdresses and feathers used for the dance (see figure 9). These dances are still performed in many of the communities, and visitors are usually required to dance, too. Indeed, during a visit to a longhouse called Long Beruang in 2013 with a group of people from nearby communities, visitors were only allowed to go to bed after every single person had performed. 
The example of the hornbill dance illustrates how some of the information that people shared during this research was not only provided verbally, but as bodily experience, for instance through learning a practice such as a dance. To learn a dance one must listen to the rhythm, watch other performers closely and try to move in the same way they do.

The embodied transmission of intangible heritage such as traditional dance can be understood without prior knowledge of the traditions of the community or its languages. This is an important consideration for the use of embodied practices in a museum context, where prior knowledge, language skills and levels of education of audiences cannot be taken for granted. This relates to some of the current themes influencing the work with photographs in Indigenous communities. In her account of returning photographs to their source communities, Lydon has pointed out that 'the current role of the photographic archive as a form of Indigenous memory ... is recuperative, intersubjective and intercultural' (Lydon, 2010: 39). The kinds of performances described above were intercultural, because they could be understood without prior knowledge about the communities. Embodied knowledge is also intersubjective because it allowed participants to transmit knowledge that could not readily be put into words. In the instances described in this article, embodied experience of cultural heritage included the experience of smoking local cigarettes, performing a dance as well as hearing songs or the music of the local instruments, and the taste of rice wine.

\section{Photographs and the conservation of material culture}

Embodied knowledge is recuperative, because the transmission and conservation of a dance depends on its continued practice. In the same way that viewing and discussing photographs among members of a group can promote circulation of oral narratives, embodied activities encourage the continued performance of traditional practices, and help to re-establish them once they have ceased. For instance, as Geismar has pointed out, the photographic archive of the Vanuatu Cultural Centre has enabled communities, staff and researchers to revive practices which had not been part of the contemporary local cultural repertoire, but which re-emerged as elements of traditional heritage (Geismar, 2009). The photographs at the centre of these projects had been 'gleaned' from the collections of various institutions, and had been inserted into a 'safe house' for local customs (Geismar, 2009: 55). Considering that the material had previously been stored at different institutions overseas, the acquisition of the photographs by the Vanuatu Cultural Centre enabled people to appropriate the photographs conceptually as they were returned into circulation within local communities.

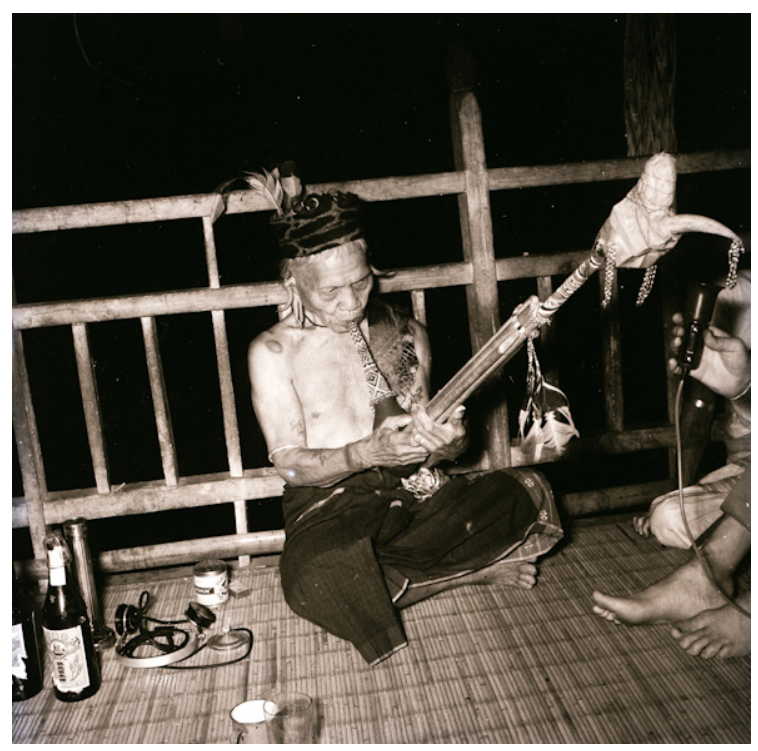

Figure 10. Datuk Moyang Jau, also known as Ukung Kajan, playing the Keledi, 1956
During this research many participants showed interest in the material culture shown in the photographs and pointed out the potential for reconstruction. For instance, a particularinstrumentcalleda kelediwas frequently shown [see figure 10]. This instrument, which was used by various Indigenous communities in Borneo, is not commonly found in Kenyah villages anymore. None of the local farmers grows the particular type of gourd that is its main component. With the photographs, Clement from Long Loyang suggested it could be possible to recreate the instrument. 'We used to hear the music on the radio, I still remember the sound,' he said. 'If you see that type of gourd, maybe you can bring some seeds and give them to me next time you come. We could plant it again here.' 


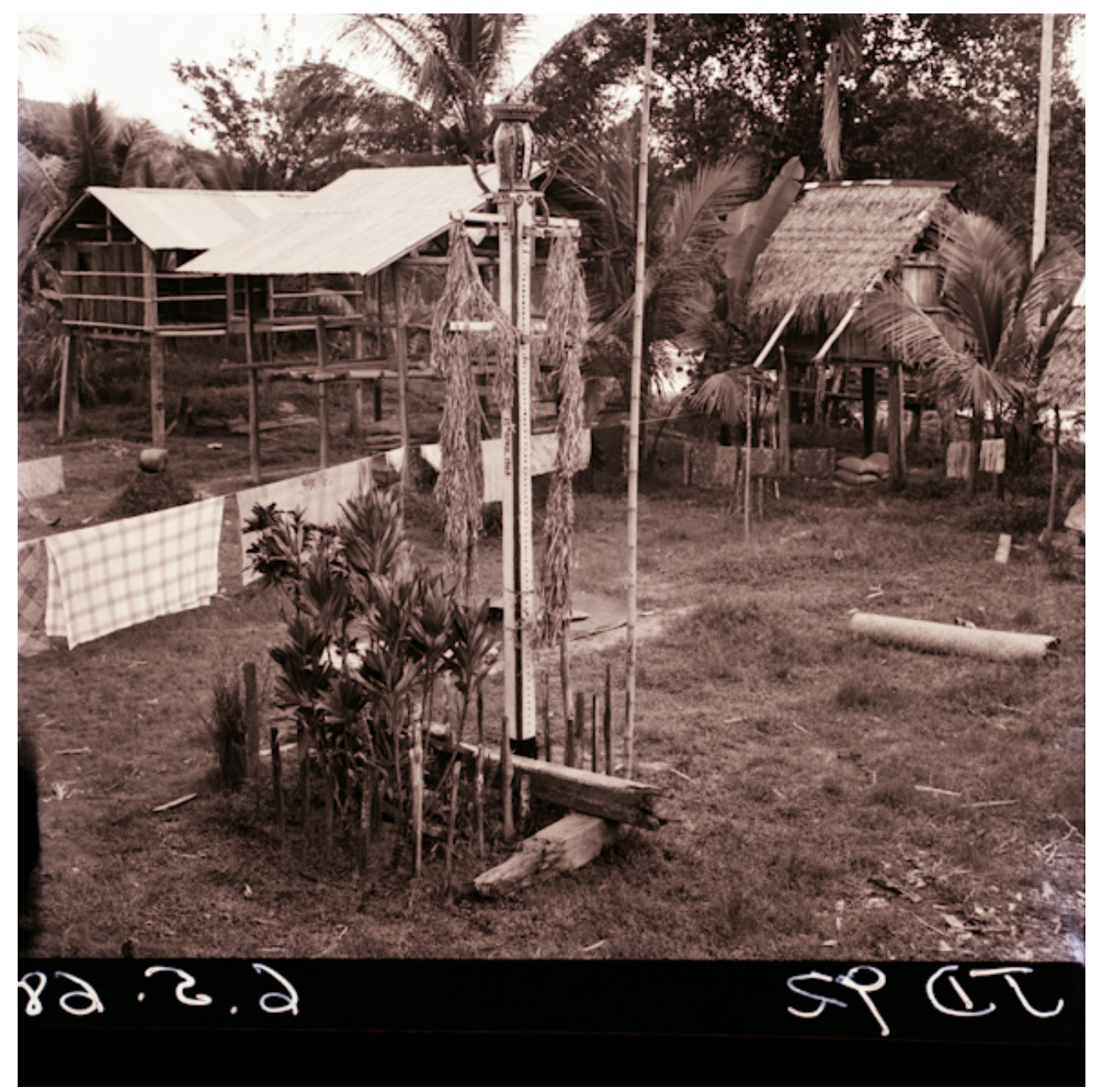

Figure 11. Keju Aren pole in Long Jegan, 1968

Recreating artifacts such as the keledi for Clement was a revival of local heritage. The wish to revive cultural heritage in the region has led to the reintroduction of several local cultural festivals in the last years, which had not been celebrated for many decades since the communities converted to Christianity. Increasingly, traditional objects are understood to be culturally meaningful even though their spiritual significance has ceased. Another instance of this became evident in the discussion of a photograph of a spirit pole or keju aren, a carved and painted wooden pole people erected in front of the longhouse in communities such as Long Jegan in the past, as part of the old traditional religion (see figure 11 and map 2). The photograph raised great interest among some people who saw it, among them Penghulu Patrick Jelaman from Long Jegan. 'It's not that we believe in the spiritual side of it anymore,' he said, looking at the photograph. 'It's important because it's our own heritage.'

Recreating objects like the keledi or the keju aren involves not only the material object itself but also the processes and materials necessary for their manufacture, and the intangible heritage to which they relate. The people in Long Jegan and Long Loyang may still be able to draw from the knowledge of the older community members, or from practices of other nearby ethnic groups with similar cultural heritage to revive these practices. They can also use the Sarawak Museum photographs as reference for recreating these artifacts. 
For museum practitioners the renewed manufacture of these objects can provide information about the objects, and could also allow engagement with the experiential and sensory elements involved in the process. For instance, while visitors may not be able to handle or use objects from the collection, they might be allowed to handle recreations of them, for instance play on the instruments. They might also try out some of the techniques and handle the materials and tools used to manufacture them. As my example above suggests, photographs can remind people of objects and the way they looked, and how they were used, and help those who want to reconstruct them. These examples point towards some of the experiential approaches through which museums could engage with their photographic archives.

\section{Embodied knowledge, communities and museums}

Collaborative co-curated projects have value both for museums and for source communities. For museums such projects can provide information about objects and related practices. They can allow museums to facilitate visitor engagements that include visual as well as experiential approaches. For communities, co-curation projects enable access to historical photographs and the provide the potential to use photographic archives for the maintenance and conservation of cultural heritage including activities and practices.

The Sarawak Museum has many opportunities to engage with source communities. Members of the various Indigenous groups make up a large percentage of visitors and staff. The Sarawak Museum continues to collect artifacts and data and carries out conservation and research projects throughout the state, and has ongoing relationships with many source communities. Apart from the objects and photographs on exhibition, there are many more tucked away in storage facilities awaiting research, description and context. Source communities can play a valuable part in this endeavour, by providing knowledge and narratives about usage, materials, techniques for manufacture and the tangible and intangible heritage related to the objects.

There are various obstacles to these collaborations. Questions as to funding, access, ownership and copyright, ethics, methodologies and social inclusion within the communities need to be addressed to ensure that institutions and communities develop equitable, reciprocal and sustainable relationships. Nevertheless, the question of how to bring embodied community response back to the museum for display is already being addressed by some museums who work particularly closely with source communities. In some instances, audio and video recordings are exhibited alongside objects. To engage audiences on a more experiential level, community responses could inform organised activities centred around objects, such as arts and crafts workshops and classes. Many museums are already practicing this. For instance, the National Museum of Vanuatu organises classes to teach children about customary sand drawing practices (Geismar, 2009, Alivizatou, 2012). Source communities could be invited for talks or seminars, or to lead activities around the production and use of museum objects. Source communities could also become involved in the renewed production of objects. For instance, source communities might produce products for the museum gift shop, enabling visitors to buy their own replica of objects to take home and contributes to the source communities' economy. The same would be possible for food and drinks sold at museum restaurants and cafes. These could sell the kinds of things produced and consumed by people in the source communities, even though this is more practical for a local museum such as the Sarawak Museum. These examples are among any number of simple measures to allow museum visitors to engage with objects and their cultural context in a more sensory way.

\section{Conclusion}

On the whole, sensory approaches to objects in archival collections, including photographs, have been slow to emerge at museums. Classen and Howes suggest that this is an ideological issue, because museum methods remain rooted in visualist origins at the cost of sensory and embodied approaches. According to this argument, " $[\mathrm{t}$ ] he traditional glass cases of the museum present little impediment to the eye but they are not ideologically transparent ... glass cases are ideological framing devices within the larger frame of the museum itself' (Classen and Howes, 2006: 218). 
However, since the emergence of a 'new museology' in the 1980s museums have undergone radical conceptual changes (Vergo, 1997). This has included efforts to turn museums into spaces of reciprocity and exchange, and to deconstruct positivist narratives in favour of more multi-vocal and democratic encounters (Graham, 2012). Collaborative work with source communities offers various ways of investigating these challenges. The work with photographic archives in particular offers itself to community co-curation projects, because photographs contain so much detailed information people can engage with, and are readily reproduced and transported. The question of ownership may be contentious in such collaborations, but this isn't always an issue for source communities. Instead, as I have discussed above, there are many ways in which such collaborations can have positive outcomes for both museums and communities, in particular with regards to continued practice and conservation of cultural heritage.

As part of new museology the role of museums as educational institutions has come into sharper focus (Boast et al., 2007, Hooper-Greenhill, 2007). Here, embodied and sensory experiences can provide learning outcomes for visitors that are personal, fluid and independent from pre-existing knowledge (Charman, 2013). Moreover, while the primacy of the visual may persist in many museums, this does not mean that a museum visit is not a sensory experience for visitors, even if these may not be immediately obvious (Hubard, 2007). Each museum has its own set of sensory characteristics. At the Sarawak Museum, they include the musty smell of the old building, the creaking wooden floorboards and the sudden gust of cold air as visitors enter the air conditioned premises. The primacy of the visual is not all-encompassing and, whether consciously or not, learning processes involve senses beyond the visual. It may therefore be helpful to engage these senses purposefully and to integrate embodied and sensory methods to promote learning at museums, for instance by linking embodied learning experiences to archival photographs. Museums could enable visitors to handle objects and tools similar to those seen in the photographs, to try activities shown in them or practice traditional songs or play Indigenous instruments, if these are the subject matter of the photographs. They could also experiment with reconstructed artifacts, with materials, tools and the processes of manufacture. Whether or not these activities can easily be integrated into the space of an exhibition may depend on the specific photographs and their content as well as the ability and willingness of museum staff to engage with source communities, and needs to be addressed for each context individually.

In this article I have argued that that a reading as a photograph as a 'text' falls short of acknowledging other practices through which a photograph can be interpreted, and that photographs like other objects depend on the oral narratives and experiential practices through which their meaning is constructed. Investigating the sensory and embodied activities which photographs promote promises to add layers of information to the knowledge about a photograph. Such embodied knowledge can establish new roles for museum collections and provide incentives for source communities to access and use the material.

Received: 8 January 2016

Finally accepted: 8 January 2018

\section{Acknowledgement}

All photographs used in the research @ Sarawak Museum, Kuching 


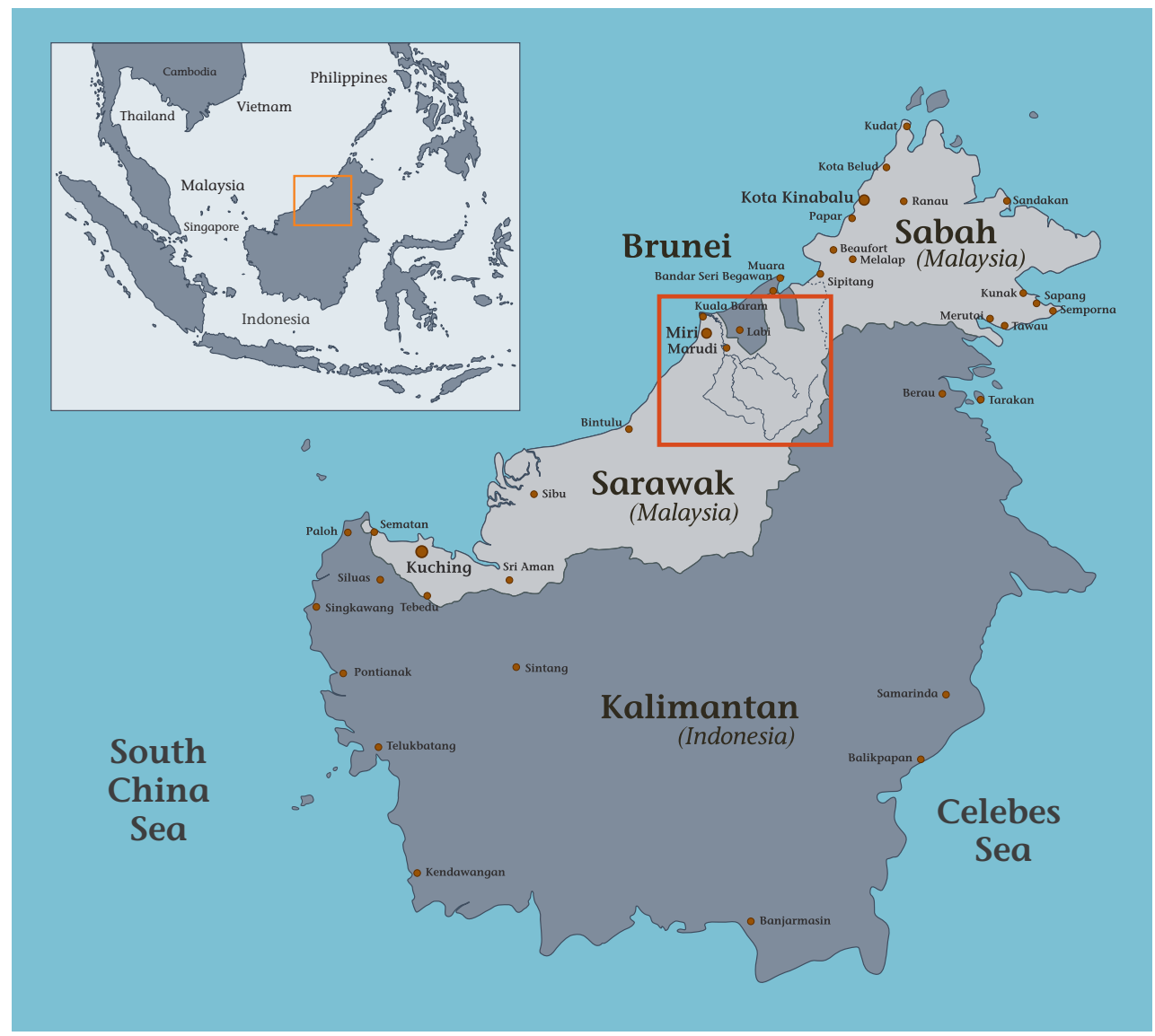

Map 1. Sarawak and the field work region 


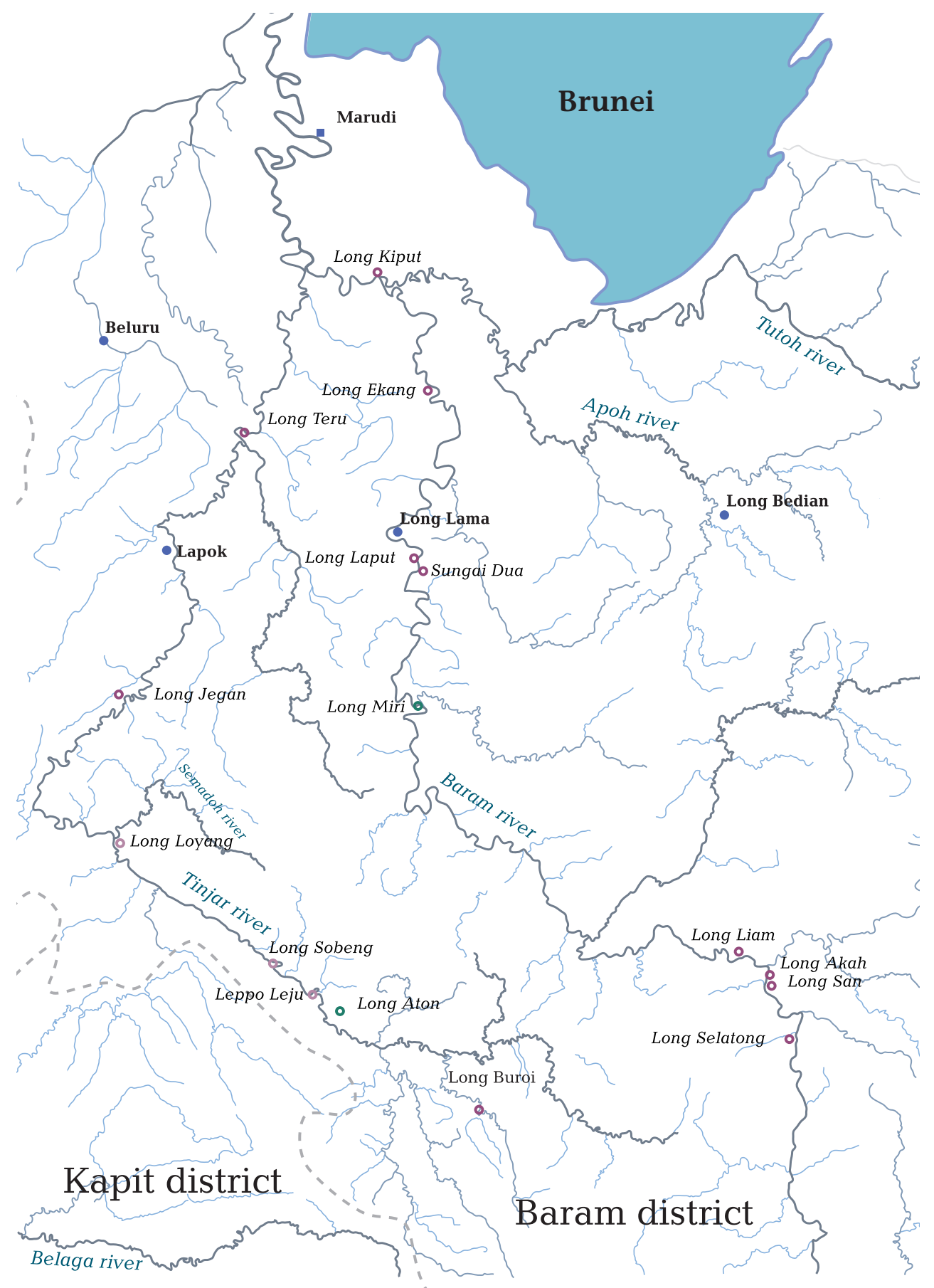

Map 2. Baram and Tinjar area 


\section{References}

Alivizatou, M. (2012) 'Debating heritage authenticity: kastom and development at the Vanuatu Cultural Centre' International Journal of Heritage Studies, 18.

Appadurai, A. (1997) The colonial backdrop. Afterimage, 24, 4-7.

Ball, M. S. \& Smith, G. W. H. (2012) 'The Use of Photographs in a Discipline of Words'in [insert editor here] Analyzing Visual Data [insert page number here], London: Sage Publications.

Bell, J. A. (2003) 'Looking to See: Reflections on Visual Repatriation in the Purari Delta, Gulf Province, Papua New Guinea' in Peers, L. \& Brown, A. (eds.) Museums and Source Communities: A Routledge Reader, [page number] London: Routledge.

Binter, J. T. (2014) 'Unruly Voices in the Museum: Multisensory Engagement with Disquieting Histories' The Senses and Society, 9, 342-360.

Bourdieu, P. (1986) The Forms of Capital Chichester, UK, Wiley-Blackwell.

Bradley, J., Adgemis, P. \& Haralampou, L. (2013) "'Why Can't They Put Their Names?”: Colonial Photography, Repatriation and Social Memory, History and Anthropology' History and Anthropology, 25, 47-71.

Candlin, F. (2004) 'Don't touch! Hands off! Art, blindness and the conservation of expertise' Body \& Society, 10, 71-90.

Christen, K. (2011) 'Opening Archives: Respectful Repatriation' The American Archivist, 74, 185-210.

Christie, M. (2008) 'Aboriginal Desert Knowledge' in Wilson, P. \& Stewart, M. (eds.) Global Indigenous Media: Cultures, Poetics, and Politics [page numbers], Durham, NC: Duke University Press.

Classen, C. (1997) 'Foundations for an Anthropology of the Senses', International Social Science Journal, 49, 401-412.

(2014) Touching the Deep Past: The Lure of Ancient Bodies in Nineteenth-Century Museums and Culture. The Senses and Society, 9, 268-283.

Classen, C. \& Howes, D. (1996) 'Making Sense of Culture: Anthropology as a Sensual Experience', Etnofoor, 86-96.

(2006) 'The museum as sensescape: Western sensibilities and indigenous artifacts', in Edwards, E., Gosden, C. \& Phillips, R. (eds.), Sensible objects: colonialism, museums and material culture, [page numbers], Oxford and New York: Berg.

lintberg, M. (2014) 'Where Publics May Touch: Stimulating Sensory Access at the National Gallery of Canada' The Senses and Society, 9, 310-322.

Curtis, N. (2006) 'Universal museums, museum objects and repatriation: The tangled stories of things', Museum Management and Curatorship, 21, 117-127.

Dibley, B. (2005) 'The Museum's Redemption: Contact Zones, Government and the Limits of Reform', International Journal of Cultural Studies, 8, 5-27.

Dobbin, K. (2013) 'Exposing Yourself a Second Time: Visual Repatriation in Scandinavian Sápmi', Visual Communication Quarterly, 20, 128-143. 
Dudley, S. (ed.) (2013) Museum Materialities: Objects, Engagements, Interpretations, Oxford and New York: Hoboken : Taylor and Francis.

Edwards, E. (2002) 'Material Beings: Objecthood and Ethnographic Photographs', Visual Studies, 17, 67-75.

(2006) 'Photographs and the Sound of History', Visual Anthropology Review, 21, $27-$ 46.

(2012) 'Objects of Affect: Photography Beyond the Image', Annual Review of Anthropology, 41, 221-234.

Edwards, E. \& Hart, J. (eds.) (2004) Photographs Objects Histories: On the Materiality of Images, London and New York: Routledge.

Edwards, E. \& Mead, M. (2013) 'Absent Histories and Absent Images: Photographs, Museums and the Colonial Past', Museums and Society, 11, 19-38.

Gadoua, M.-P. (2014) 'Making Sense through Touch: Handling Collections with Inuit Elders at the McCord Museum', The Senses and Society, 9, 323-341.

Geisbusch, J. (2012) 'For Your Eyes Only? The Magic Touch of Relics' in Dudley, S. (ed.) Museum Objects: Experiencing the Properties of Things, [page numbers] London and New York: Routledge.

Geismar, H. (2009) 'The Photograph and the Malanggan: Rethinking Images on Malakula, Vanuatu', The Australian Journal of Anthropology, 20, 48-73.

Horn, C. (2012) Orang Ulu of Borneo: Photographs From the Archives of the Sarawak Museum, Kota Kinabalu, Malaysia, Opus Publications.

Hose, C. (1894) 'The Natives of Borneo', The Journal of the Anthropological Institute of Great Britain and Ireland, 23, 156-172.

(1900) 'In the Heart of Borneo', The Geographical Journal, 16, 39-59.

Hose, C. \& McDougall, W. (1901) 'The Relations Between Men and Animals in Sarawak', The Journal of the Anthropological Institute of Great Britain and Ireland, 31, 173-213.

Howes, D. (1990) 'Controlling textuality: a call for a return to the senses', Anthropologica, [issue number], 55-73.

(2003) Sensual relations: Engaging the senses in culture and social theory, University of Michigan Press.

(2012) 'The Cultural Life of the Senses', Postmedieval: a journal of medieval cultural studies, 3, 450-454.

(2014a) 'Introduction to Sensory Museology', The Senses and Society, 9, 259-267.

(2014b) 'The Secret of Aesthetics Lies in the Conjugation of the Senses' The Multisensory Museum: Cross-Disciplinary Perspectives on Touch, Sound, Smell, Memory, and Space, 285.

Howes, D. \& Classen, C. (2013), Ways of Sensing: Understanding the Senses in Society, Routledge.

Hubard, O. M. (2007), 'Complete Engagement: Embodied Response in Art Museum Education', Art Education, [issue number], 46-53. 
Isaac, G. (2011) 'Whose Idea Was This?' Current Anthropology, 52, 211-233.

Janke, T. \& lacovino, L. (2012) 'Keeping Cultures Alive: Archives and Indigenous Cultural and Intellectual Property Rights', Archival Science, 12, 151-171.

Johnson, K. M. (2015) 'Rethinking (re) doing: Historical Re-enactment and/as Historiography', Rethinking History, 19, 193-206.

Levent, N. \& Pascual-Leone, A. (2014), The Multisensory Museum: Cross-Disciplinary Perspectives on Touch, Sound, Smell, Memory, and Space, Rowman \& Littlefield.

Lydon, J. (2010) 'Return: The Photographic Archive and Technologies of Indigenous Memory', Photographies, 3, 173-187.

Marstine, J. (2008) New Museum Theory and Practice: An Introduction, Malden, MA; Cambridge, UK; Melbourne, AU, Wiley / Blackwell.

Maxwell, A. (2013) 'Modern anthropology and the problem of the racial type: The photographs of Franz Boas', Visual Communication, 12, 123-142.

Modest, W. (2014) 'Museums and the Emotional Afterlife of Colonial Photographs', in Edwards, E. \& Lien, S. (eds.) Uncertain Images: Museums and the Work of Photographs [page numbers], Farnham, UK: Ashgate Publishing, Ltd.

Nieuwenhuis, A. W. (1904) Quer durch Borneo: Ergebnisse seiner Reisen in den Jahren 1894, 1896-97 und 1898-1900, Leiden, E.J. Brill.

Pallasmaa, J. (2014) 'Museum as an Embodied Experience', in Levent, N. \& PascualLeone, A. (eds.) The Multi-Sensory Museum: Cross-Disciplinary Perspectives on Touch, Sound, Smell, Memory, and Space [page numbers], Maryland / Plymouth, UK: Rowman \& Littlefield.

Peers, L. \& Brown, A. K. (2009a), 'Colonial Photographs and Post-Colonial Histories: The Kainai-Oxford Photographic Histories Project' in Timpson, A. M. (ed.) First Nations, First Thoughts: The Impact of Indigenous Thought in Canada [page numbers], Vancouver: UBC Press.

Pels, P. (1997), 'The Anthropology of Colonialism: Culture, History, and the Emergence of Western Governmentality', Annual Review of Anthropology, 26, 163-183.

Phillips, R. (2003) 'Introduction to Part 3' in Peers, L. \& Brown, A. K. (eds.) Museums and Source Communities: A Routledge Reader, [page numbers], London and New York: Routledge.

Pickering, M. (2015) “The Big Picture”: the repatriation of Australian Indigenous sacred objects', Museum Management and Curatorship, 30, 427-443.

Pinney, C. (2011) Photography and Anthropology, London, Reaktion Books.

Poignant, R. (2004) Professional savages: captive lives and western spectacle, New Haven and London, Yale University Press.

Pye, E. (2016), The power of touch: handling objects in museum and heritage context, Routledge.

Simpson, M. (2009a) 'Museums and restorative justice: Heritage, repatriation and cultural education', Museum Internationa, 61, 122 -129. 
(2009b), 'Museums and restorative justice: heritage, repatriation and cultural education', Museum International, 61, 121-129.

Smith, D. A. (2008) 'From Nunavut to Micronesia: Feedback and Description, Visual Repatriation and Online Photographs of Indigenous Peoples' Partnership: The Canadian Journal of Library and Information Practice and Research, 3, 1-19.

Smith, L. T. (1999) Decolonizing Methodologies: Research and Indigenous Peoples, London and New York, Zed books.

Srinivasan, R. (2012) 'Re-Thinking the Cultural Codes of New Media: The Question Concerning Ontology', New Media \& Society, 15, 203-223.

Standal, Ø. F. \& Moe, V. F. (2011) 'Merleau-Ponty meets Kretchmar: Sweet tensions of embodied learning', Sport, Ethics and Philosophy, 5, 256-269.

Wood, E. \& Latham, K. F. (2011) 'The Thickness of the World: Exploring the Curriculum of Museums through Phenomenological Touch', Journal of Curriculum Theorizing, 27.

${ }^{*}$ Christine Horn has been working at the Swinburne Institute for Social Research (SISR) since 2010, graduating from Swinburne in 2015 with a PhD thesis about photographs from the Sarawak Museum archive in Malaysia. Before SISR Christine spent three years teaching communication and design at Swinburne University in Sarawak, during which she worked together with the Sarawak Museum in several exhibitions. She holds an MA from UNIMAS, University of Malaysia Sarawak, and an undergraduate degree in Graphic Design and Communication from London Metropolitan University.

Christine Horn

Postdoctoral fellow,

The Swinburne Institute for Social Research,

Swinburne University,

Melbourne,

Australia

Mail

53 PO Box

218 Hawthorn,

Victoria,

3122 Australia

chorn@swin.edu.au

tel: 0061432469736 